\title{
SWINE WASTEWATER ASSOCIATED WITH MINERAL FERTILIZATION ON CORN CROP (Zea mays)
}

\section{NATHALIE C. H. KESSLER ${ }^{1}$, SILVIO C. SAMPAIO ${ }^{2}$, MAUREN SORACE ${ }^{3}$, SHAIANE D. LUCAS ${ }^{4}$, DENISE PALMA ${ }^{5}$}

\begin{abstract}
This study aimed to evaluate the agronomical and environmental aspects in corn, soil characteristics and leachate resulting from the material combination of swine wastewater and mineral fertilizer in the long run. The experimental area has a history of swine wastewater application for experiments conducted since 2006, this being the seventh crop cycle in the area. Four doses of swine wastewater $\left(0 ; 100 ; 200\right.$ and $\left.300 \mathrm{~m}^{3} \mathrm{ha}^{-1}\right)$ associated with presence and absence of mineral fertilizer were applied, consisting of eight treatments. The results obtained were subjected to variance analysis and means compared by Tukey test at $5 \%$ significance. We conclude that the swine wastewater can be partially used as an alternative fertilizer, since the $\mathrm{P}$ and $\mathrm{Mn}$ are complemented with specific fertilization. There must be carefulness about $\mathrm{Fe}^{+2}, \mathrm{Cu}^{+2}$ and $\mathrm{Zn}^{+2}$ accumulation in soil, and also to the concentrations of $\mathrm{Fe}^{+2}, \mathrm{Cu}^{+2}, \mathrm{Zn}^{+2}, \mathrm{NO}_{3}{ }^{-}+\mathrm{NO}_{2}{ }^{-}$and $\mathrm{Na}^{+}$in leachate which exceeded the limits at the highest SWW applied levels.
\end{abstract}

KEYWORDS: manure, soil fertility, water reuse.

\section{ÁGUA RESIDUÁRIA DA SUINOCULTURA ASSOCIADA À ADUBAÇÃO MINERAL NO MILHO (Zea mays)}

RESUMO: O presente trabalho teve como objetivo avaliar os aspectos ambientais e agronômicos na cultura do milho, características do solo e do material percolado decorrentes da associação de água residuária da suinocultura e adubação mineral, em longo prazo. A área experimental possui histórico de aplicação de água residuária da suinocultura, com experimentos conduzidos desde 2006, sendo este o sétimo ciclo de cultura conduzido na área. Foram aplicadas quatro doses de água residuária da suinocultura $\left(0 ; 100 ; 200\right.$ e $\left.300 \mathrm{~m}^{3} \mathrm{ha}^{-1}\right)$ associadas à ausência e presença de adubação mineral, consistindo em oito tratamentos. Os resultados obtidos foram submetidos à análise de variância, e as médias, comparadas pelo teste de Tukey, a 5\% de significância. Conclui-se que a água residuária da suinocultura pode ser parcialmente utilizada como fertilizante alternativo, desde que o $\mathrm{P}$ e o $\mathrm{Mn}$ sejam complementados com adubação específica. Deve-se ter cuidado com o acúmulo de $\mathrm{Fe}^{+2}, \mathrm{Cu}^{+2}$ e $\mathrm{Zn}^{+2}$ no solo, e também para as concentrações de $\mathrm{Fe}^{+2}, \mathrm{Cu}^{+2}, \mathrm{Zn}^{+2}, \mathrm{NO}_{3}{ }^{-}+$ $\mathrm{NO}_{2}{ }^{-}$e $\mathrm{Na}^{+}$no percolado, que excederam os limites nas maiores doses de ARS aplicadas.

PALAVRAS-CHAVE: dejetos suínos, fertilidade do solo, reúso de água.

\section{INTRODUCTION}

Corn crop undergoes significant technological changes in order to increase productivity. In this context, we emphasize the need to improve soil quality, to reach a sustained production, through appropriate management, which includes everything from crop rotation, to the direct planting and soil fertility management (CRUZ et al., 2009).

\footnotetext{
${ }^{1}$ Bióloga, Doutoranda, Programa de Pós-Graduação em Engenharia Agrícola, UNIOESTE, Cascavel - PR, Fone: (45) 32203175, nathalie.kessler@gmail.com

${ }^{2}$ Eng ${ }^{-}$Agrícola, Prof. Dr., Programa de Pós-Graduação em Eng. Agrícola, UNIOESTE, Cascavel - PR, silvio.sampaio@unioeste.br

${ }^{3}$ Bióloga, Prof. Dra., Departamento de Ciências Agrárias, UEM, Umuarama - PR, mauren_band@hotmail.com

${ }^{4}$ Tecnóloga em Gerenciamento Ambiental, Doutoranda, Programa de Pós-Graduação em Engenharia Agrícola, UNIOESTE, Cascavel - PR, shaianelucas@gmail.com

${ }^{5}$ Bióloga, Doutoranda, Programa de Pós-Graduação em Eng. Agrícola, UNIOESTE, Cascavel - PR, palmadenise@yahoo.com.br Recebido pelo Conselho Editorial em: 31-10-2012

Aprovado pelo Conselho Editorial em: 10-12-2013
} 
The remaining wastewater, as a residue with high content of organic matter and other nutrients, especially nitrogen and phosphorus, is capable of providing improvements in physical, chemical and biological properties of the soil, providing nutrients for crop and still bringing to the producer a productivity increasement and cost reduction (SCHERER et al., 2007).

However, it is essential to know the characteristics of the wastewater and their potential impacts on the environment. Authors like AITA \& GIACOMINI (2008), BERWANGER et al. (2008), CAOVILLA et al. (2010) and SAMPAIO et al. (2010a) who evaluated the negative impacts of the swine wastewater application in soil, such as fertility problems and toxicity resulting from accumulation of ions in soil. Other authors also claim that the manure application is prone to surface and groundwater contamination due to surface and vertical displacement of these ions accumulated in soil (PRIOR et al, 2009; SAMPAIO et al., 2010b; SMANHOTTO et al., 2010; MAGGI et al., 2011; LUCAS et al., 2013).

Thus, the present study aimed to evaluate the agronomical and environmental aspects in corn, soil characteristics and leachate resulting from the material combination of swine wastewater and mineral fertilizer in the long run.

\section{MATERIAL AND METHODS}

The experiment was conducted in the field, with coordinates $24^{\circ} 48^{\prime}$ south latitude and $53^{\circ} 26^{\prime}$ west longitude, at an altitude of $760 \mathrm{~m}$. The climate is subtropical mesothermal super humid, with average annual rainfall of $1,800 \mathrm{~mm}$. The town has an average temperature of $20^{\circ} \mathrm{C}$ and relative humidity averaged 75\% (IAPAR, 1998). Precipitated rain blades and daily averages observed during cultivation of corn evaluated temperatures are shown in Figure 1.

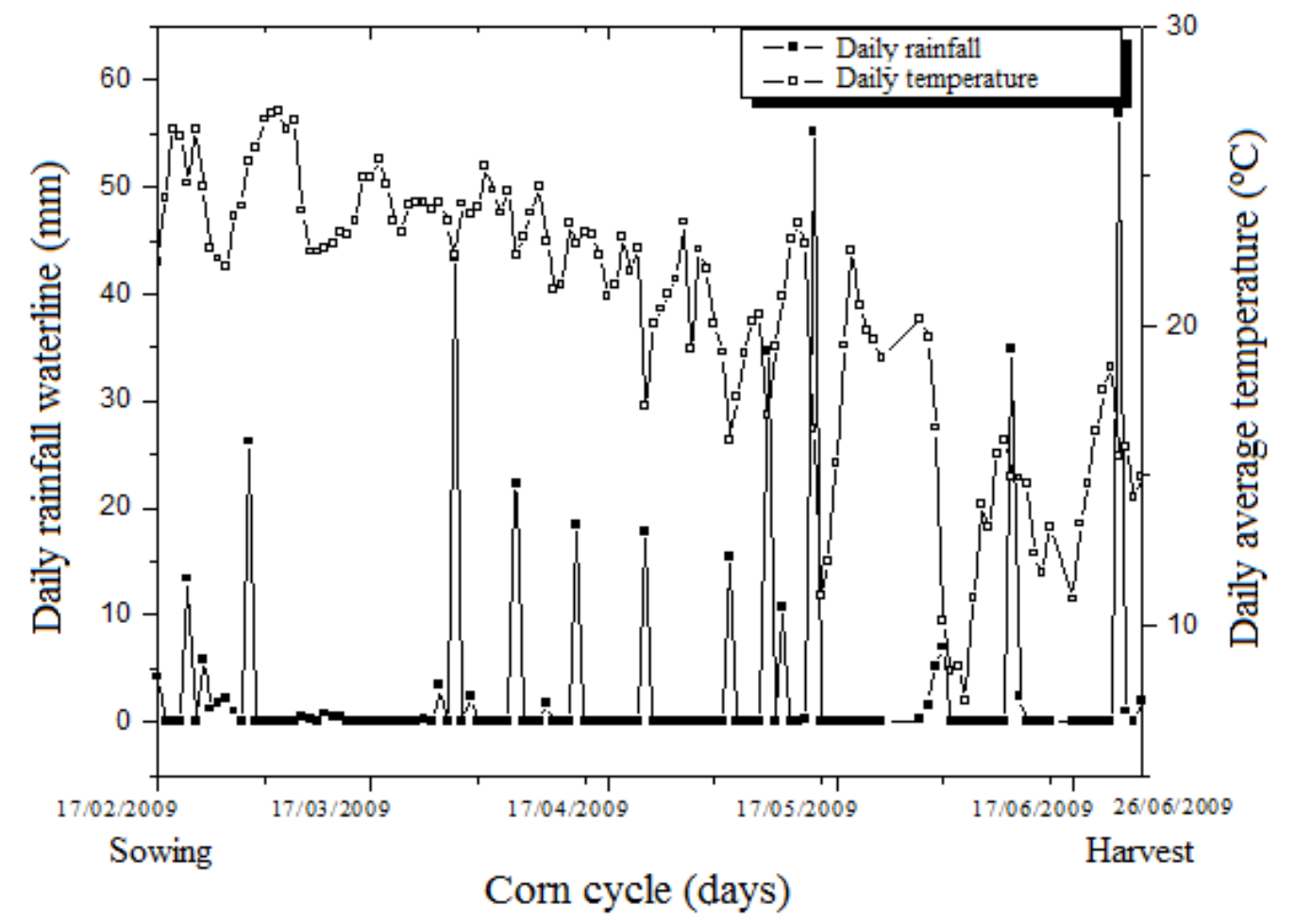

SIMEPAR (2012)

FIGURE 1. Distribution of daily rainfall waterline and average temperatures during the experiment.

The experimental area soil is classified as a typical Red Dystroferric Oxisol (EMBRAPA, 2006). The area has a history of swine wastewater application with experiments conducted since 2006, following the cycles of corn, soybean, oat, soybean, oat, baby corn, with this experiment, corn, the seventh crop cycle conducted in the experimental area. In Table 1 are shown the total nutrients applied via swine wastewater (SWW), the previous and current production cycles. 
TABLE 1. Total of nutrients $\left(\mathrm{kg} \mathrm{ha}^{-1}\right)$ applied via swine wastewater (SWW) and mineral fertilizer (MF) by treatment, in six previous cycles and current $7^{\text {th }}$ production cycle.

\begin{tabular}{|c|c|c|c|c|c|c|c|c|}
\hline Treatments* & $\mathrm{N}$ & $\mathrm{P}$ & $\mathrm{K}^{+}$ & $\mathrm{N}$ & $\mathrm{P}$ & $\mathrm{K}^{+}$ & $\mathrm{Cu}^{+2}$ & $\mathrm{Zn}^{+2}$ \\
\hline \multicolumn{4}{|c|}{ Total applied via MF on previous cycles } & \multicolumn{5}{|c|}{ Total applied via SWW on previous cycles } \\
\hline 0 SWW-A & 0.00 & 0.00 & 0.00 & 0.00 & 0.00 & 0.00 & 0.00 & 0.00 \\
\hline 0 SWW-P & 67.50 & 220.00 & 135.00 & 0.00 & 0.00 & 0.00 & 0.00 & 0.00 \\
\hline 100 SWW-A & 0.00 & 0.00 & 0.00 & 402.80 & 91.02 & 260.42 & 2.58 & 15.60 \\
\hline 100 SWW-P & 67.50 & 220.00 & 135.00 & 395.30 & 91.02 & 260.42 & 2.58 & 15.60 \\
\hline 200 SWW-A & 0.00 & 0.00 & 0.00 & 817.58 & 181.71 & 518.83 & 5.14 & 31.20 \\
\hline 200 SWW-P & 67.50 & 220.00 & 135.00 & 810.08 & 181.71 & 518.83 & 5.14 & 31.20 \\
\hline 300 SWW-A & 0.00 & 0.00 & 0.00 & 1235.38 & 272.22 & 779.25 & 7.72 & 46.79 \\
\hline 300 SWW-P & 67.50 & 220.00 & 135.00 & 1227.88 & 272.22 & 779.25 & 7.72 & 46.79 \\
\hline \multicolumn{4}{|c|}{ Total applied via MF on current cycle } & \multicolumn{5}{|c|}{ Total applied via SWW on current cycle } \\
\hline 0 SWW-A & 0.00 & 0.00 & 0.00 & 0.00 & 0.00 & 0.00 & 0.00 & 0.00 \\
\hline 0 SWW-P & 120.00 & 80.00 & 90.00 & 0.00 & 0.00 & 0.00 & 0.00 & 0.00 \\
\hline 100 SWW-A & 0.00 & 0.00 & 0.00 & 24.64 & 6.94 & 8.55 & 0.07 & 0.65 \\
\hline 100 SWW-P & 120.00 & 80.00 & 90.00 & 24.64 & 6.94 & 8.55 & 0.07 & 0.65 \\
\hline 200 SWW-A & 0.00 & 0.00 & 0.00 & 49.28 & 13.88 & 17.10 & 0.14 & 1.30 \\
\hline 200 SWW-P & 120.00 & 80.00 & 90.00 & 49.28 & 13.88 & 17.10 & 0.14 & 1.30 \\
\hline 300 SWW-A & 0.00 & 0.00 & 0.00 & 73.92 & 20.83 & 25.65 & 0.12 & 1.95 \\
\hline 300 SWW-P & 120.00 & 80.00 & 90.00 & 73.92 & 20.83 & 25.65 & 0.12 & 1.95 \\
\hline
\end{tabular}

* Treatments: 0 SWW-A: $0 \mathrm{~m}^{3} \mathrm{ha}^{-1}$ of swine wastewater and absence of mineral fertilizer; $0 \mathrm{SWW}-\mathrm{P}: 0 \mathrm{~m}^{3} \mathrm{ha}^{-1}$ of swine wastewater and the presence of mineral fertilizer; $100 \mathrm{SWW}-\mathrm{A}: 100 \mathrm{~m}^{3} \mathrm{ha}^{-1}$ of swine wastewater and absence of mineral fertilizer; $100 \mathrm{SWW}$-P: $100 \mathrm{~m}^{3} \mathrm{ha}^{-1}$ of swine wastewater and the presence of mineral fertilizer; $200 \mathrm{SWW}-\mathrm{A}: 200 \mathrm{~m}^{3} \mathrm{ha}^{-1}$ of swine wastewater and absence of mineral fertilizer; $200 \mathrm{SWW}-\mathrm{P}: 200 \mathrm{~m}^{3} \mathrm{ha}^{-1}$ of swine wastewater and the presence of mineral fertilizer; $300 \mathrm{SWW}-\mathrm{A}: 300 \mathrm{~m}^{3} \mathrm{ha}^{-1}$ of swine wastewater and absence of mineral fertilizer; 300SWW-P: $300 \mathrm{~m}^{3} \mathrm{ha}^{-1}$ of swine wastewater and the presence of mineral fertilizer; $\mathrm{N}$ : nitrogen; $\mathrm{P}$ phosphorus; $\mathrm{K}^{+}$: potassium; $\mathrm{Cu}^{+2}$ : copper; $\mathrm{Zn}^{+2}$ : zinc.

The experimental area is made of twenty-four percolation lysimeters, spread over an area of $90 \mathrm{~m}^{2}(15 \times 6 \mathrm{~m})$. Lysimeters consist of fiber boxes with $1 \mathrm{~m}^{3}$ volume, $1.60 \mathrm{~m}^{2}$ area, $0.91 \mathrm{~m}$ depth, and 1.43 m diameter; thus, each box comprises an experimental plot.

The SWW used was collected in the district of Tres Bocas, the city of Toledo (Paraná State) in a rural property that offers an integrated approach to waste treatment biosystem. The SWW was treated in anaerobic digester followed by sedimentation tank and stabilization pond. The outlet tube biodigester was the collection point. After collection, the SWW was applied to the soil once ten days before sowing.

The doses applied in the area were defined by SMANHOTTO (2008), which was based on nitrogen concentration found in SWW to form a record. Thus, the doses in SWW were 100; 200; $300 \mathrm{~m}^{3} \mathrm{ha}^{-1}$ applied ten days before sowing associating with absence and presence of mineral fertilizer (MF), which consisted of 100\% recommended for corn (Table 1). The treatments applied to experimental plots consisted of a control (OSWW-A), a mineral (0SWW-P), and the remaining six control treatments: a 100SWW, 100SWW-P, 200SWW-A, 200SWW-P, 300SWW-A, 300SWW-P.

The agronomic indixes were plant height $(\mathrm{PH})$, stem diameter (SD), dry matter (DM), leaf number (LN) and nutritional analysis (N, P, K $\mathrm{Ca}^{+2}, \mathrm{Na}^{+}, \mathrm{Zn}^{+2}, \mathrm{Cu}^{+2}, \mathrm{Mn}, \mathrm{Mg}^{+2}, \mathrm{Fe}^{+2}$ and S), according to PRIOR (2008) adapted method. Three plant leaves per plot were randomly chosen and homogenised to obtain samples per plot. 
TABLE 2. Swine wastewater characterization.

\begin{tabular}{|c|c|c|c|c|c|}
\hline Parameter & Value & Parameter & Value & Parameter & Value \\
\hline $\mathrm{pH}_{\left(\mathrm{CaCl}^{2}\right)}^{2}$ & 7.57 & $\mathrm{Mg}^{2+}\left(\mathrm{mg} \mathrm{L}^{-1}\right)$ & 48.00 & COD (mg L $\left.{ }^{-1}\right)$ & 1378.00 \\
\hline $\mathrm{N}\left(\mathrm{mg} \mathrm{L}^{-1}\right)$ & 265.10 & $\mathrm{Cu}^{+2}\left(\mathrm{mg}^{-\mathrm{L}^{-1}}\right)$ & 0.72 & $\mathrm{TS}\left(\mathrm{mg} \mathrm{L}^{-1}\right)$ & 11720.00 \\
\hline $\mathrm{N}_{\mathrm{ORG}}\left(\mathrm{mg} \mathrm{L}^{-1}\right)$ & 18.70 & $\mathrm{Zn}^{+2}\left(\mathrm{mg} \mathrm{L}^{-1}\right)$ & 6.50 & TFS (mg L $\left.{ }^{-1}\right)$ & 1128.00 \\
\hline $\mathrm{N}_{\text {INORG }}\left(\mathrm{mg} \mathrm{L}^{-1}\right)$ & 246.40 & $\mathrm{Fe}^{+2}\left(\mathrm{mg} \mathrm{L}^{-1}\right)$ & 1.91 & $\mathrm{VS}\left(\mathrm{mg} \mathrm{L}^{-1}\right)$ & 10592.00 \\
\hline $\mathrm{NH}_{4}^{+}\left(\mathrm{mg} \mathrm{L}^{-1}\right)$ & 168.00 & $\operatorname{Mn}\left(\mathrm{mg} \mathrm{L}^{-1}\right)$ & 0.85 & TDS (mg L $\left.{ }^{-1}\right)$ & 348.00 \\
\hline $\mathrm{NO}_{3}^{-}+\mathrm{NO}_{2}^{-}\left(\mathrm{mg} \mathrm{L}^{-1}\right)$ & 78.40 & $\mathrm{~B}\left(\mathrm{mg} \mathrm{L}^{-1}\right)$ & 0.37 & FDS $\left(\mathrm{mg} \mathrm{L}^{-1}\right)$ & 320.00 \\
\hline TOC $\left(\mathrm{mg} \mathrm{L}^{-1}\right)$ & 40500.00 & $\mathrm{~S}\left(\mathrm{mg} \mathrm{L}^{-1}\right)$ & 18.24 & VDS $\left(\mathrm{mg} \mathrm{L}^{-1}\right)$ & 28.00 \\
\hline $\mathrm{P}\left(\mathrm{mg} \mathrm{L}^{-1}\right)$ & 69.44 & Turbidity (NTU) & 298.50 & TSS (mg L $\left.{ }^{-1}\right)$ & 11372.00 \\
\hline $\mathrm{K}^{+}\left(\mathrm{mg} \mathrm{L}^{-1}\right)$ & 86.50 & $\mathrm{EC}\left(\mu \mathrm{S} \mathrm{m}^{-1}\right)$ & 1299.00 & $\mathrm{FSS}\left(\mathrm{mg} \mathrm{L}^{-1}\right)$ & 808.00 \\
\hline $\mathrm{Na}^{+}\left(\mathrm{mg} \mathrm{L}^{-1}\right)$ & 79.20 & SAR $\left(\mathrm{mmol} \mathrm{L}^{-1}\right)$ & 2.98 & $\operatorname{VSS}\left(\mathrm{mg} \mathrm{L}^{-1}\right)$ & 10564.00 \\
\hline $\mathrm{Ca}^{2+}\left(\mathrm{mg} \mathrm{L}^{-1}\right)$ & 46.00 & COD-F (mg L $\left.{ }^{-1}\right)$ & 281.00 & & \\
\hline
\end{tabular}

APHA Protocol; Awwa; Wef (1995). $\mathrm{N}$ : total nitrogen; $\mathrm{N}_{\mathrm{ORG}}$ : organic nitrogen; $\mathrm{N}_{\mathrm{INORG}}$ : inorganic nitrogen; $\mathrm{NH}_{4}{ }^{+}:$ammonium; $\mathrm{NO}_{2}^{-}+\mathrm{NO}_{3}^{-}$: nitrite + nitrate; TOC: total organic carbon; P: phosphorus, $\mathrm{K}^{+}$: potassium; $\mathrm{Na}^{+}$: sodium; $\mathrm{Ca}^{2+}$ : calcium; $\mathrm{Mg}^{2+}$ : magnesium; $\mathrm{Cu}^{+2}$ : copper; $\mathrm{Zn}^{+2}$ : zinc; $\mathrm{Fe}^{+2}$ : iron; $\mathrm{Mn}$ : manganese; $\mathrm{B}$ : boron; S: sulphur; EC: electrical conductivity; SAR: sodium adsorption ratio; COD-F : chemical oxygen demand - filtered; COD: chemical oxygen demand; TS: total solids; TFS: total fixed solids; VS: solid volatile; TDS: total dissolved solids; FDS: fixed dissolved solids; VDS: volatile dissolved solids; TSS: total suspended solids; FSS: fixed suspended solids; VSS: volatile suspended solids.

Soil samples were collected at baseline, before SWW application, and sowing, and at the end of the experiment, at corn cycle end (26/06/2009) using a dutch auger at 0 from $0.00-0.20 ; 0.20$ 0.40 and $0.40-0.60 \mathrm{~m}$ depths across experimental plot profile, which were homogenised and then removed a fraction for $\mathrm{pH}, \mathrm{OM}, \mathrm{P}, \mathrm{K}^{+}, \mathrm{Ca}^{2+}, \mathrm{Mg}^{2+}, \mathrm{CEC}, \mathrm{Cu}^{+2}, \mathrm{Zn}^{+2}, \mathrm{Na}^{+}, \mathrm{EC}, \mathrm{N}, \mathrm{N}_{\text {inorg }}, \mathrm{N}_{\text {org }} \mathrm{NO}_{3}{ }^{-}$ $+\mathrm{NO}_{2}^{-}, \mathrm{NH}_{4}{ }^{+}$, BS and $\mathrm{V} \%, \mathrm{~m} \%$ and the $\mathrm{H}+\mathrm{Al}^{3+}$, according to TEDESCO et al. (1995), EMBRAPA (1997) and RAIJ et al. (2001) methods. An average of the three depths was obtained per plot.

Leachate material sampling occurred twice: after first rainfall (21/02/2009), and last rainfall (23/06/2009) during corn cycle, with water line of $13.4 \mathrm{~mm}$ and $56.8 \mathrm{~mm}$, respectively. For each sample were determined: $\mathrm{pH}, \mathrm{EC}, \mathrm{N}_{\text {total }}, \mathrm{NO}_{3}{ }^{-}+\mathrm{NO}_{2}{ }^{-}, \mathrm{P}, \mathrm{Cu}^{+2}, \mathrm{Zn}^{+2}, \mathrm{Ca}^{2+}, \mathrm{Mg}^{2+}, \mathrm{Na}^{+}$and $\mathrm{K}^{+}$in accordance with APHA et al. (1995) and TEDESCO et al. (1995).

The experiment was carried out during 2009 in no-tillage system, and CD 223 AP corn cultivar (COODETEC) in a seeding rate of 20 seed per meter, and $0.45 \mathrm{~m}$ row spacing. Soil fertilization consisted of NPK (00:20:20 formulation) applied at sowing at $250 \mathrm{~kg} \mathrm{ha}^{-1}$ dose.

The experimental design was randomized in blocks with treatments in a factorial scheme $(4 \times 2)$ with three replications. Four SWW levels $\left(0 ; 100 ; 200 ; 300 \mathrm{~m}^{3} \mathrm{ha}^{-1}\right.$ in the cycle) and two fertilization levels (absence and presence of mineral fertilizer) were applied.

Data were submitted to descriptive statistics and normality verification. For non-normal distribution parameters changes based on Yeo-Johnson transformation were made. Then, variance analysis was performed and means compared by Tukey test at $5 \%$ significance. Statistical analyzes were performed separately for plant, soil, and leachate in each collection period.

\section{RESULTS AND DISCUSSION}

\section{Agronomic variables}

Table 3 shows the results for parameters related to the corn leaf analysis.

The leaf P content was different for both factors, SWW and MF, whose averages were higher in 0SWW and 300SWW doses, also in the MF presence. MENEGHETTI (2010), in an experiment with baby corn, also found significance for P content when applied SWW. VELOSO (2010) observed reduction in foliar $\mathrm{P}$ concentrations compared to control when pig litter was applied in corn, in contrast to this study results. 
TABLE 3. Variance analysis (p-value) and mean test for corn foliar diagnosis parameters.

\begin{tabular}{|c|c|c|c|c|c|c|c|c|c|c|c|c|c|c|c|}
\hline $\begin{array}{l}\text { MF and } \\
\text { SWW }\end{array}$ & $\mathrm{P}$ & $\mathrm{K}^{+}$ & $\mathrm{Ca}^{2+}$ & $\mathrm{Mg}^{2+}$ & $\mathrm{Cu}^{+2}$ & Mn & $\mathrm{LN}$ & MF*SWW & $\mathrm{N}$ & $\mathrm{Zn}^{+2}$ & $\mathrm{Fe}^{+2}$ & S & $\mathrm{PH}$ & DM & SD \\
\hline$\S 0$ & 1.61ab & $16.25 a$ & $.95 b$ & $1.94 \mathrm{~b}$ & 5.74a & $48.27 a$ & $10.50 \mathrm{a}$ & $90 \mathrm{~A}$ & 18.11abA & $10.25 \mathrm{abA}$ & 152.32bB & $1.36 \mathrm{bA}$ & aA & 2.96aA & $23.68 \mathrm{bA}$ \\
\hline$\S 100$ & $1.40 \mathrm{a}$ & 17.68ab & $2.87 \mathrm{a}$ & $1.72 \mathrm{ab}$ & $6.17 a$ & $43.80 \mathrm{a}$ & $10.61 \mathrm{a}$ & $90 \mathrm{P}$ & $26.09 \mathrm{aB}$ & 7.77aA & 93.03aA & $1.77 \mathrm{aB}$ & $211.55 \mathrm{aB}$ & $4.95 \mathrm{aB}$ & $26.64 \mathrm{aB}$ \\
\hline$\S 200$ & $1.54 a b$ & 18.43ab & 2.91a & $1.62 \mathrm{ab}$ & $6.27 \mathrm{a}$ & $47.23 a$ & $10.78 \mathrm{a}$ & 『100 A & 14.98aA & 7.77aA & $\mathrm{abA}$ & $1.02 \mathrm{aA}$ & $179.00 \mathrm{bA}$ & 3.64abA & $20.15 \mathrm{aA}$ \\
\hline$\S 300$ & $1.79 b$ & $19.86 \mathrm{~b}$ & $2.78 \mathrm{a}$ & $1.42 \mathrm{a}$ & 7.59a & $48.72 \mathrm{a}$ & $10.95 a$ & \100 P & 28.79aB & 12.37abB & 102.49abA & $1.65 \mathrm{aB}$ & $211.56 \mathrm{aB}$ & $4.65 \mathrm{aB}$ & 25.43aB \\
\hline$\S \mathrm{A}$ & $1.43 \mathrm{~A}$ & $5.82 \mathrm{~A}$ & $3.11 \mathrm{~A}$ & $1.86 \mathrm{~A}$ & 6 6.69A & $37.54 \mathrm{~A}$ & $10.39 \mathrm{~A}$ & ๆ200 A & $20.72 b A$ & 10.25abA & 96.18aA & 1.23abA & $188.94 \mathrm{bcA}$ & 4.19bcA & $23.63 \mathrm{bA}$ \\
\hline$\S \mathrm{P}$ & 1.74 & $19.29 \mathrm{~B}$ & $3.15 \mathrm{~A}$ & 9B & $6.20 \mathrm{~A}$ & $56.47 \mathrm{~B}$ & $11.03 \mathrm{~A}$ & \200 P & & $18.38 \mathrm{bcB}$ & 129.30abB & & & & $27.84 \mathrm{aB}$ \\
\hline- & - & - & - & - & - & - & - & ๆ300 A & 26.23cA & $15.55 \mathrm{bA}$ & 108.17aA & $1.47 \mathrm{bA}$ & 211.22cA & $4.70 \mathrm{cA}$ & $23.68 \mathrm{bA}$ \\
\hline- & - & - & - & - & - & - & - & \300 P & 30.33aB & $21.56 \mathrm{cB}$ & $130.87 \mathrm{bA}$ & 1.63aA & 214.11aA & $4.82 \mathrm{aB}$ & $26.70 \mathrm{aB}$ \\
\hline MF & $0.02 *$ & $0.02 *$ & 4 & $0.05^{*}$ & 0.12 & $0.00 *$ & 0.11 & & $0.00 *$ & 0.0 & 0.4 & $0.02 *$ & $0.00 *$ & $0.00^{*}$ & $0.00 *$ \\
\hline SWW & $0.00 *$ & $0.00^{*}$ & $0.01 *$ & $0.01 *$ & 0.36 & 0.76 & 0.85 & SWW & $0.00 *$ & $0.01 *$ & 0.51 & $0.00 *$ & $0.00 *$ & $0.00 *$ & $0.00 *$ \\
\hline $\begin{array}{c}\text { SWW* }^{*} \\
\text { MF }\end{array}$ & 0.06 & 0.56 & 0.60 & 0.50 & 0.34 & 0.41 & 0.66 & $\mathrm{SWW}^{*} \mathrm{MF}$ & $0.01 *$ & $0.02 *$ & $0.00 *$ & $0.03 *$ & $0.00^{*}$ & $0.00^{*}$ & $0.03^{*}$ \\
\hline $\mathrm{VC}(\%)$ & 11.44 & 9.30 & 16.96 & 17.36 & 19.90 & 18.47 & 8.62 & VC (\%) & 8.00 & 19.95 & 13.19 & 8.17 & 6.26 & 6.81 & 4.26 \\
\hline
\end{tabular}

$\S$ Means followed by the same lower case letter in the column do not differ by Tukey test at 5\% significance for SWW and means followed by the same capital letter in the column do not differ by Tukey test at $5 \%$ significance for MF. ๆ Means followed by the same lower case letter in the column do not differ by Tukey test at 5\% significance for the SWW breakdown by MF and means followed by the same capital letter in the column do not differ by Tukey test at $5 \%$ significance level for the MF means breakdown by SWW.

A: MF absence; P: MF presence; *: Significant at 5\%; VC: variation coefficient; Macronutrients expressed in $\mathrm{g} \mathrm{kg}^{-1}$; Micronutrients expressed in $\mathrm{mg} \mathrm{kg}^{-1}$; $\mathrm{PH}$ and SD in $\mathrm{cm}$; and DM expressed in $\mathrm{mg}$.

The potassium $\left(\mathrm{K}^{+}\right)$increase in leaves was significant for both factors, and increased proportionally with the SWW and MF applications. CERETTA et al. (2005) found similar results where $\mathrm{K}^{+}$concentration in manure is readily available to plant which differed from this study. However, SEIDEL et al. (2010) did not observe significant difference in $\mathrm{K}^{+}$foliar levels in corn, using 20, 30, 40 and $50 \mathrm{~m}^{3} \mathrm{ha}^{-1}$ of SWW from stabilization lagoon, and NPK (10;100 and $45 \mathrm{~kg} \mathrm{ha}^{-1}$ ) chemical fertilization.

The $\mathrm{Ca}^{2+}$ ion showed decreasing value for the SWW as application rates increased and the highest average was observed at 0SWW. According to MEDEIROS et al. (2008), this lowest $\mathrm{Ca}^{2+}$ concentration is justified by competition for the same ion-exchange site in absorption process among calcium, magnesium and potassium ions.

Regarding to $\mathrm{Mg}^{2+}$ content, an inversely proportional behavior was found for SWW application; however, directly proportional to MF. A similar result was described by MENEGHETTI (2010), who found greater $\mathrm{Mg}^{2+}$ concentrations as nitrogen fertilization increased. PRIOR (2008) and SEIDEL et al. (2010) did not find significant $\mathrm{Mg}^{2+}$ amounts in corn leaf tissue at varied application levels. By contrast, OLIVEIRA et al. (2004) found $\mathrm{Mg}^{2+}$ foliar contents statistically greater with SWW application when compared to control. Nevertheless, for Mn ion, there were significant values only for MF factor, being higher in its presence.

The $\mathrm{Cu}^{+}$content and leaf number showed no significant difference between treatments.

The SWW statistical breakdown by MF, for $\mathrm{N}$ content, presented an increase according to SWW application with or without MF. In MF statistical breakdown by SWW, values were always higher with the presence than with SWW absence. This corroborates to the findings of CERETTA et al. (2005) and PRIOR (2008), who also observed $\mathrm{N}$ accumulation in accordance with the increased waste use in corn leaf.

Regarding the $\mathrm{Zn}^{+2}$ content, SWW statistical breakdown by MF, an increase was found as the SWW doses were elevated, either in the MF absence or presence. These results are similar to those found by MENEGHETTI (2010) for foliar levels in baby corn. There was no statistical difference in MF statistical breakdown by SWW only to OSWW treatment; but for others, the averages were higher in MF presence. PRIOR (2008) also observed an increase in $\mathrm{Zn}^{+2}$ concentration in corn leaf when SWW doses were higher. 
The $\mathrm{Fe}^{+2}$ content, in SWW statistical breakdown by MF, was biased increased with higher SWW doses in MF presence. In the other hand, in MF absence, averages decreased as SWW doses increased. This result demonstrates that although both factors were significant at the $5 \%$ level, the MF presence was more important for $\mathrm{Fe}^{+2}$ absorption. The statistical breakdown of MF by SWW, for 0 and 100SWW doses, averages were lower with MF, where as at 200 and 300SWW doses, they were higher. OLIVEIRA et al. (2004) found no statistical difference in $\mathrm{Fe}^{+2}$ leaf concentrations for plants fertigated with different wastewater sources and control.

The sulfur (S) content in SWW statistical breakdown by MF obtained higher averages for 0 and 300SWW treatments without MF; however, its presence generated highest average for 0 and 200SWW treatments. For the inverse breakdown, the highest values were observed in MF presence except for 300SWW treatment, which averaged statistically equal. MENEGHETTI (2010) reported $\mathrm{S}, \mathrm{P}, \mathrm{Ca}^{2+}$ and $\mathrm{Mg}^{2+}$ increase with higher SWW doses.

For the variable plant height (PH) when breaking down SWW by MF, averages increased significantly with SWW addition in both presence and absence. The same occurred for MF within SWW, where averages were higher in MF presence. The same was observed by FREITAS et al. (2004) and PRIOR (2008), who reported an increase in plant corn with SWW addition. CESARINO (2006) found higher values for plant height in corn fertilized with SWW.

In dry matter (DM), the SWW statistical breakdown by MF, treatments with MF showed statistically similar averages. However, in absence, there was visible raise in average concomitantly with SWW increasing doses due to the greater nutrient availability. In MF breakdown, averages are higher in the MF presence. CERETTA et al. (2005) also found higher corn dry matter yield as application dose grew.

To stem diameter (SD), averages of MF in SWW were statistically higher for MF presence at all SWW doses. In the SWW within MF, all values were statistically similar in MF presence.

All evaluated doses showed heavy metal contents in leaf within range recommended by RAIJ (1991). Thus, $\mathrm{Cu}^{+2}$ and $\mathrm{Zn}^{+2}$ content in mature leaves were 3 to $20 \mathrm{mg} \mathrm{kg}^{-1}$ and 10 to $50 \mathrm{mg} \mathrm{kg}^{-1}$, respectively.

The $\mathrm{P}$ and Mn content parameters have not reached the proper minimum values recommended by MALAVOLTA (2006), which are $2.5 \mathrm{~g} \mathrm{~kg}^{-1}$ and $50 \mathrm{mg} \mathrm{kg}^{-1}$, respectively. However, $\mathrm{N}$ and S only reached 27.5 and $1.5 \mathrm{~g} \mathrm{~kg}^{-1}$, respectively, in MF presence. According to EMBRAPA (1996), metabolic disruption may occur when there is micronutrient deficiency, and also macronutrient deficiency. In addition, excessive wastewater application can be more harmful than the plant deficiency. PRIOR (2008) states that it is extremely important to promote a proper nutrient balance, since their imbalance in soil can unfavorably act in crop yield.

\section{Soil variables}

Parameters such as $\mathrm{pH}, \mathrm{K}^{+}, \mathrm{Na}^{+}, \mathrm{V} \%$ and $\mathrm{H}+\mathrm{Al}^{3+}$ at the beginning of the cycle, as shown in Table 4, showed a significant difference for MF factor. But the highest means were found only for $\mathrm{K}^{+}$and $\mathrm{H}+\mathrm{Al}^{3+}$ with MF. The $\mathrm{K}^{+}$content in soil also showed a significant difference for SWW, it is possible to observe the raise with SWW addition. Therefore, for soils that received higher SWW doses, there was an increase in potassium concentration and accumulation. DOBLINSKI et al. (2010) reported $\mathrm{K}^{+}$accumulation in soil due to its low mobility as it is adsorbed by soil.

QUEIROZ et al. (2004) evaluated pig manure effect in fodder plant crop and also observed $\mathrm{K}^{+}$accumulation in soil, as well as ASSMANN et al. (2009) found a raise in $\mathrm{K}^{+}$values with increased liquid swine manure addition at 0;20;40; 80 and $120 \mathrm{~m}^{3} \mathrm{ha}^{-1}$ rates during two pasture cycles, following the crop sequence: white-oat + ryegrass / corn (Zea mays) / white-oat + ryegrass / soybean (Glycine max), with six effluent applications during the two years of study. 
At the end of the cycle, the ions $\mathrm{K}^{+}$and $\mathrm{Na}^{+}$were the parameters that had a significant difference at 5\% for SWW. It was possible to infer that both increase proportionally as the doses of application of SWW increase.

TABLE 4. Variance analysis (p-value) and mean test for soil parameters at the beginning and end of the corn crop.

\begin{tabular}{|c|c|c|c|c|c|c|c|c|c|c|c|}
\hline \multicolumn{12}{|c|}{ Cycle Begginning } \\
\hline MF and SWW & $\mathrm{pH}$ & $\mathrm{OM}$ & $\mathrm{EC}$ & $\mathrm{N}$ & $\mathrm{NO}_{3}{ }^{-}+\mathrm{NO}_{2}^{-}$ & Ninorg & Norg & $\mathrm{NH}_{4}{ }^{+}$ & $\mathrm{P}$ & $\mathrm{K}^{+}$ & $\mathrm{Ca}^{2+}$ \\
\hline$\S 0$ & $6.32 \mathrm{a}$ & $20.76 a$ & - & $1.04 \mathrm{a}$ & $1.02 \mathrm{a}$ & - & - & - & $8.50 a$ & $0.16 \mathrm{a}$ & $5.09 a$ \\
\hline$\S 100$ & $6.08 \mathrm{a}$ & 21.09a & - & $1.06 \mathrm{a}$ & $1.10 \mathrm{a}$ & - & - & - & $10.51 \mathrm{a}$ & $0.29 a b$ & 4.13a \\
\hline$\S 200$ & $6.23 a$ & $19.86 a$ & - & $0.99 a$ & $1.03 \mathrm{a}$ & - & - & - & $9.23 \mathrm{a}$ & $0.37 a b$ & $4.42 \mathrm{a}$ \\
\hline$\S 300$ & $6.28 \mathrm{a}$ & 19.83a & - & $0.99 a$ & $0.96 a$ & - & - & - & $9.00 \mathrm{a}$ & $0.48 \mathrm{~b}$ & $4.64 a$ \\
\hline$\overline{\S A}$ & $6.38 \mathrm{~B}$ & $21.09 \mathrm{~A}$ & - & $1.05 \mathrm{~A}^{\mathrm{a}}$ & $1.04 \mathrm{~A}$ & - & - & - & $8.06 \mathrm{~A}$ & $0.26 \mathrm{~A}$ & $4.87 \mathrm{~B}$ \\
\hline$\S \mathrm{P}$ & $6.08 \mathrm{~A}$ & $19.68 \mathrm{~A}$ & - & $0.99 \mathrm{~A}$ & $1.02 \mathrm{~A}$ & - & - & - & $10.56 \mathrm{~A}$ & $0.39 \mathrm{~B}$ & $4.27 \mathrm{~A}$ \\
\hline $\mathrm{MF}$ & $0.02 *$ & 0.46 & - & 0.47 & 0.78 & - & - & - & 0.36 & $0.05^{*}$ & $0.02 *$ \\
\hline SWW & 0.50 & 0.95 & - & 0.95 & 0.60 & - & - & - & 0.96 & $0.01 *$ & 0.49 \\
\hline $\mathrm{SWW}^{*} \mathrm{MF}$ & 0.27 & 0.89 & - & 0.89 & 0.98 & - & - & - & 0.88 & 0.49 & 0.66 \\
\hline$\overline{\mathrm{VC}}(\%)$ & 4.47 & 22.62 & - & 22.58 & 16.38 & - & - & - & 68.93 & 43.89 & 23.62 \\
\hline MF and SWW & $\mathrm{Mg}^{2+}$ & $\mathrm{Na}^{+}$ & $\mathrm{Cu}^{+2}$ & $\mathrm{Zn}^{+2}$ & $\mathrm{Mn}$ & $\mathrm{Fe}^{+2}$ & BS & CEC & V\% & $\mathrm{m} \%$ & $\mathrm{H}+\mathrm{Al}^{3+}$ \\
\hline$\S 0$ & $3.41 \mathrm{a}$ & $2.67 a$ & $9.82 \mathrm{a}$ & $1.75 \mathrm{a}$ & $51.92 \mathrm{a}$ & $109.75 a$ & $8.65 a$ & $11.85 \mathrm{a}$ & $72.67 a$ & - & $3.06 a$ \\
\hline$\S 100$ & $2.68 a$ & $1.83 a$ & $10.06 \mathrm{a}$ & $1.78 \mathrm{a}$ & $46.62 a$ & $109.62 a$ & $7.09 a$ & $10.70 \mathrm{a}$ & 64.83a & - & $3.61 \mathrm{a}$ \\
\hline$\S 200$ & $2.68 \mathrm{a}$ & 2.33a & $10.32 \mathrm{a}$ & $2.02 \mathrm{a}$ & $46.91 \mathrm{a}$ & 111.67a & 7.46a & 10.73a & 68.83a & - & $3.26 \mathrm{a}$ \\
\hline$\S 300$ & $2.78 \mathrm{a}$ & $2.17 \mathrm{a}$ & $9.98 \mathrm{a}$ & $2.53 a$ & 48.43a & $106.22 \mathrm{a}$ & 7.91a & $10.84 a$ & $72.17 \mathrm{a}$ & - & $2.93 a$ \\
\hline$\S \mathrm{A}$ & $3.09 \mathrm{~A}$ & $2.58 \mathrm{~B}$ & $10.17 \mathrm{~A}$ & $2.24 \mathrm{~A}$ & $52.82 \mathrm{~A}$ & $112.71 \mathrm{~A}$ & $8.22 \mathrm{~A}$ & $11.21 \mathrm{~A}$ & $72.75 B$ & - & $2.92 \mathrm{~A}$ \\
\hline$\S \mathrm{P}$ & $2.68 \mathrm{~A}$ & $1.92 \mathrm{~A}$ & $9.91 \mathrm{~A}$ & $1.80 \mathrm{~A}$ & $44.11 \mathrm{~A}$ & $105.92 \mathrm{~A}$ & 7.34A & $10.84 \mathrm{~A}$ & $66.50 \mathrm{~A}$ & - & $3.51 \mathrm{~B}$ \\
\hline$\overline{\mathrm{MF}}$ & 0.09 & $0.07 *$ & 0.33 & 0.48 & 0.13 & 0.34 & 0.20 & 0.50 & $0.04 *$ & - & $0.01^{*}$ \\
\hline SWW & 0.12 & 0.42 & 0.59 & 0.79 & 0.89 & 0.95 & 0.39 & 0.40 & 0.19 & - & 0.15 \\
\hline $\mathrm{SWW} * \mathrm{MF}$ & 0.61 & 0.39 & 0,18 & 0.60 & 0.95 & 0,10 & 0.69 & 0.97 & 0.31 & - & 0.17 \\
\hline VC (\%) & 19.47 & 37.72 & 6.27 & 74.60 & 2.28 & 15.54 & 20.43 & 11.85 & 9.48 & - & 15.65 \\
\hline \multicolumn{12}{|c|}{ Final do Ciclo } \\
\hline MF and SWW & $\mathrm{pH}$ & $\mathrm{OM}$ & EC & $\mathrm{N}$ & $\mathrm{NO}_{3}{ }^{-}+\mathrm{NO}_{2}^{-}$ & Ninorg & Norg & $\mathrm{NH}_{4}{ }^{+}$ & $\mathrm{P}$ & $\mathrm{K}^{+}$ & $\mathrm{Ca}^{2+}$ \\
\hline §0 & $7.17 \mathrm{a}$ & $22.50 \mathrm{a}$ & $98.62 a$ & $998.67 a$ & $3.00 \mathrm{a}$ & $11.83 a$ & $987.17 \mathrm{a}$ & $9.00 \mathrm{a}$ & $4.52 \mathrm{a}$ & $2.37 \mathrm{a}$ & 72.53a \\
\hline$\S 100$ & 7.03a & $20.83 a$ & $82.92 a$ & $956.67 a$ & $4.00 \mathrm{a}$ & $15.17 a$ & 941.83a & 11.33a & $2.35 a$ & $2.61 a$ & $71.83 a$ \\
\hline$\S 200$ & $6.79 a$ & $20.83 a$ & $93.37 \mathrm{a}$ & $1057.00 \mathrm{a}$ & 3.33a & $12.50 \mathrm{a}$ & 1044.83a & $9.00 \mathrm{a}$ & $3.85 a$ & $3.40 \mathrm{ab}$ & $62.07 a$ \\
\hline$\S 300$ & $6.99 a$ & $20.33 a$ & $108.07 a$ & $865.67 a$ & $4.17 \mathrm{a}$ & $13.67 \mathrm{a}$ & $852.17 a$ & $9.67 \mathrm{a}$ & $3.73 a$ & $4.67 \mathrm{~b}$ & $65.80 \mathrm{a}$ \\
\hline §A & $7.07 \mathrm{~A}$ & $21.58 \mathrm{~A}$ & $90.42 \mathrm{~A}$ & $997.50 \mathrm{~A}$ & $3.33 \mathrm{~A}$ & $12.42 \mathrm{~A}$ & $985.50 \mathrm{~A}$ & $9.08 \mathrm{~A}$ & $2.88 \mathrm{~A}$ & $2.80 \mathrm{~A}$ & $69.70 \mathrm{~A}$ \\
\hline$\S \mathrm{P}$ & $6.92 \mathrm{~A}$ & $20.67 \mathrm{~A}$ & 101.07A & $941.50 \mathrm{~A}$ & $3.92 \mathrm{~A}$ & $14.17 \mathrm{a}$ & $927.50 \mathrm{~A}$ & $10.42 \mathrm{~A}$ & $4.35 \mathrm{~A}$ & $3.72 \mathrm{~A}$ & $66.42 \mathrm{~A}$ \\
\hline MF & 0.40 & 0.60 & 0.31 & 0.50 & 0.26 & 0.11 & 0.48 & 0.09 & 0.06 & 0.07 & 0.59 \\
\hline SWW & 0.52 & 0.82 & 0.40 & 0.42 & 0.33 & 0.16 & 0.41 & 0.12 & 0.25 & $0.02 *$ & 0.57 \\
\hline $\mathrm{SWW} * \mathrm{MF}$ & 0.56 & 0.59 & 0.63 & 0.99 & 0.91 & 0.74 & 0.99 & 0.57 & 0.65 & 0.98 & 0.40 \\
\hline VC (\%) & 6.24 & 19.62 & 26.09 & 20.41 & 33.25 & 19.15 & 20.55 & 18.30 & 49.77 & 35.72 & 21.72 \\
\hline MF and SWW & $\mathrm{Mg}^{2+}$ & $\mathrm{Na}^{+}$ & $\mathrm{Cu}^{+2}$ & $\mathrm{Zn}^{+2}$ & $\mathrm{Mn}$ & $\mathrm{Fe}^{+2}$ & SB & CEC & $\mathrm{V} \%$ & $\mathrm{~m} \%$ & $\mathrm{H}+\mathrm{Al}^{3+}$ \\
\hline$\S 0$ & $21.08 \mathrm{a}$ & $0.47 \mathrm{a}$ & $8.55 a$ & $2.08 a$ & 55.33a & $29.17 a$ & $96.30 \mathrm{a}$ & 120.33a & 79.83a & $1.87 \mathrm{a}$ & $23.83 a$ \\
\hline$\S 100$ & $20.85 a$ & $0.68 a b$ & $8.73 a$ & $1.92 \mathrm{a}$ & $48.83 a$ & $28.67 a$ & $95.97 a$ & 119.17a & $80.17 a$ & 1.73 & $23.22 \mathrm{a}$ \\
\hline$\S 200$ & $20.42 a$ & $0.78 b$ & 8.93a & $1.73 a$ & $46.50 \mathrm{a}$ & $29.17 a$ & $86.67 a$ & 114.33a & 75.83a & 1.48a & $27.65 a$ \\
\hline$\S 300$ & $20.57 a$ & $0.80 \mathrm{~b}$ & $8.55 a$ & $2.77 \mathrm{a}$ & 46.33a & $28.50 \mathrm{a}$ & $92.02 \mathrm{a}$ & 113.17a & $80.67 a$ & $1.52 \mathrm{a}$ & $21.15 \mathrm{a}$ \\
\hline §A & $20.95 \mathrm{~A}$ & $0.75 \mathrm{~A}$ & $8.66 \mathrm{~A}$ & $2.02 \mathrm{~A}$ & $48.75 \mathrm{~A}$ & $28.00 \mathrm{~A}$ & $94.11 \mathrm{~A}$ & $115.75 \mathrm{~A}$ & $80.83 \mathrm{~A}$ & $1.71 \mathrm{~A}$ & $21.65 \mathrm{~A}$ \\
\hline$\S \mathrm{P}$ & $20.51 \mathrm{~A}$ & $0.62 \mathrm{~A}$ & $8.73 \mathrm{~A}$ & $2.23 \mathrm{~A}$ & $49.75 \mathrm{~A}$ & $29.75 \mathrm{~A}$ & $91.37 \mathrm{~A}$ & $117.75 \mathrm{~A}$ & $77.42 \mathrm{~A}$ & $1.59 \mathrm{~A}$ & $26.28 \mathrm{~A}$ \\
\hline$\overline{M F}$ & 0.07 & 0.07 & 0.87 & 0.56 & 0.82 & 0.38 & 0.68 & 0.68 & 0.31 & 0.64 & 0.21 \\
\hline SWW & 0.20 & $0.01 *$ & 0.89 & 0.24 & 0.42 & 0.99 & 0.71 & 0.66 & 0.71 & 0.65 & 0.62 \\
\hline $\mathrm{SWW}^{*} \mathrm{MF}$ & 0.28 & 0.36 & 0.60 & 0.49 & 0.65 & 0.28 & 0.45 & 0.68 & 0.42 & 0.64 & 0.39 \\
\hline VC (\%) & 2.64 & 23.92 & 11.53 & 41.62 & 21.00 & 16.30 & 17.42 & 10.06 & 9.98 & 35.96 & 35.64 \\
\hline
\end{tabular}

$\S$ Means followed by the same lower case letter in the column do not differ by Tukey test at 5\% significance for SWW and means followed by the same capital letter in the column do not differ by Tukey test at $5 \%$ significance for MF.

A: MF absence; P: MF presence; *: Significant at 5\%; VC: variation coefficient; Amounts expressed in $\mathrm{mg} \mathrm{dm}^{-3}$; except for OM, CEC, $\mathrm{K}^{+}, \mathrm{Cu}^{+2}, \mathrm{Ca}^{2+}, \mathrm{Mg}^{2+}, \mathrm{Na}^{+2}, \mathrm{BS}, \mathrm{H}+\mathrm{Al}^{3+}$ expressed in mmol dm${ }^{-1}$ and EC expressed in $\mathrm{mS} \mathrm{m}^{-1}$.

FREITAS et al. (2004) state that swine wastewater addition to soil, the $\mathrm{K}^{+}$levels increase, since this effluent is rich in such nutrients. These results were also found by QUEIROZ et al. (2004), in a Red-Yellow Podzolic soil in Rio Grande do Sul, by SILVA et al. (2007), in RedYellow Oxisol in Paraná and DAL BOSCO et al. (2008) in Red Dystroferric Oxisol.

MENEGHETTI (2010) evaluated 0; 100; 200 and $300 \mathrm{~m}^{3} \mathrm{~h}^{-1}$ doses during baby corn cultivation showed an increase in $\mathrm{Na}^{+}$soil concentration, when SWW doses were higher. 
According to GONÇALVES et al. (2007), a raise in soil $\mathrm{Na}^{+}$, compared to $\mathrm{Ca}^{2+}$ and $\mathrm{Mg}^{2+}$, is subject to risks associated with soil physical structure changes by clay dispersion, aggregate disruption and pore clogging reducing permeability, infiltration rate and plant water uptake.

Even though not being significant at the $5 \%$ level, it was possible to observe a growing trend of $\mathrm{Zn}^{+2}$ in relation to SWW increasing doses. The same pattern repeats for $\mathrm{Cu}^{+2}$, which was similar to the results observed by GIROTTO et al. (2010), who reported its accumulation in Paludalf Soil with SWW application during six years of cultivation with crop rotation. LUCAS et al. (2013) observed accumulation of $\mathrm{Cu}^{+2}$ and $\mathrm{Zn}^{+}$in Red Dystroferric Oxisol after four years SWW application associated with mineral fertilization on crop rotation (corn, black-oat and soybean), showing their power of accumulation over time.

The $\mathrm{Cu}^{+2}, \mathrm{Fe}^{+2}, \mathrm{Zn}^{+}$ions exceed the limits of $0.8 ; 1.5$ and $30 \mathrm{mg} \mathrm{dm}^{-3}$, respectively, according to RAIJ et al. (2001), which agrees with results reported by KESSLER et al. (2013) that showed the accumulation of these metals in soils cultivated with soybeans under SWW fertilization. The results of this study show that successive SWW applications might accumulate certain elements in soil, as reported by LUCAS et al. (2013), and moreover, can still cause toxicity problems, leaching down the soil profile and also washed down by runoff contaminating water bodies.

Excess $\mathrm{Fe}^{+2}$ in soils can be explained by the high $\mathrm{P}$ concentrations, since this inhibits the iron absorption by plants forming insoluble complexes. The $\mathrm{Fe}^{+2}$ accumulations may also be attributed to imbalance in relation to copper, which affects its availability to plants. The high $\mathrm{Zn}^{+}$concentration is also a probable cause, since $\mathrm{Fe}^{+2}$ concentrations tend to reduce in plants with excess of $\mathrm{Zn}^{+}$(RAIJ et al., 1991).

In the end of the cycle, there was a decrease in $\mathrm{Ca}^{2+}$ and $\mathrm{Mg}^{2+}$ contents, although not significant, with increasing SWW doses. These data are opposite to the results found by other authors, as SCHERER et al. (2007), who found increased levels of $\mathrm{K}^{+}, \mathrm{Ca}^{2+}$ and $\mathrm{Mg}^{2+}$ in a field experiment; however, also not significant at the 5\% level, with SWW application.

For the CEC factor, a negative effect occurred with increasing levels of SWW observed at the end of the crop cycle, but it was not significant. According to PRIOR et al. (2009), the soil low CEC is attributed to acid soil $\mathrm{pH}$.

For V\%, only the MF factor at the cycle beginning was statistically significant at $5 \%$ level, but this factor was higher in MF abscence than in its presence.

\section{Leachate variables}

At the beginning of the cycle, as shown in Table 5, the $\mathrm{Na}^{+}$ion was significant for SWW factor, showing statistically significant differences at $200 \mathrm{~m}^{3} \mathrm{~h}^{-1}$, which had the highest means. The sodium content boost, in agricultural soils, might bring losses by increasing salinity, changing soil physical characteristics by clay dispersion and chemical characteristics, influencing directly or indirectly the plant development (FEIGIN et al., 1991).

At the beginning of the cycle, there was a significant interaction for $\mathrm{Fe}^{+2}$, whose highest mean was observed at 200 dose. This result is probably due to the combination of $\mathrm{Fe}^{+2}$ content, slightly higher in $200 \mathrm{~m}^{3} \mathrm{~h}^{-1}$ plot present in soil at the beginning of the cycle (Table 4) together with the Fe content from SWW treatment (Table 2) and lower plant uptake in the absence of MF (Table 3), contributing to a higher its content in leachate.

The EC had significantly higher mean values with the addition of MF at the end of the cycle.

At the end of the cycle, there was a significant interaction in $\mathrm{pH}$, which tended to reduce with increasing doses of SWW. These results contrast with those found by MAGGI et al. (2011), who found no changes in $\mathrm{pH}$ due to the SWW application and chemical fertilization.

Although not significant, higher $\mathrm{K}^{+}$values were observed with application of $200 \mathrm{~m}^{3} \mathrm{ha}^{-1}$ of SWW. These results corroborate to those exposed by ANAMI et al. (2008), MAGGI et al. (2011) 
and MENEGHETTI (2010), who found a higher potassium concentration in the leachate in treatments with larger SWW amounts, which justifies this result by the high concentration of this element in such effluent. Moreover, according MAGGI et al. (2011), the result is also found linked to the fact that $\mathrm{K}^{+}$is a movable element in soil and is subjected to leaching. BERTOL et al. (2010) reinforces this idea, stating that $\mathrm{K}^{+}$has low reactivity with soil which may cause an increased mobility. Previously, KING et al. (1985) warned about the application of high manure rates, where $\mathrm{Ca}^{2+}$ and $\mathrm{Mg}^{2+}$ may be displaced from exchange sites by the waste ions such as $\mathrm{Na}^{+}, \mathrm{K}^{+}$and $\mathrm{NH}_{4}{ }^{+}$, and can be moved to deeper layers by leaching.

TABLE 5. Variance analysis (F) and average test for leachate soil parameters during corn crop.

\begin{tabular}{|c|c|c|c|c|c|c|c|c|c|c|c|c|c|}
\hline \multicolumn{14}{|c|}{ Cycle beginning } \\
\hline MF and SWW & EC & $\mathrm{NO}_{3}{ }^{-}+\mathrm{NO}_{2}{ }^{-}$ & $\mathrm{K}^{+}$ & $\mathrm{Ca}^{+2}$ & $\mathrm{Mg}^{+2}$ & $\mathrm{Na}^{+}$ & $\mathrm{Cu}^{+2}$ & $\mathrm{Zn}^{+2}$ & $\mathrm{pH}$ & $\mathrm{Fe}^{+2}$ & MF*SWW & $\mathrm{pH}$ & $\mathrm{Fe}^{+2}$ \\
\hline$\S 0$ & $220.62 a$ & $2.35 a$ & $14.31 \mathrm{a}$ & $18.62 \mathrm{a}$ & $6.61 \mathrm{a}$ & 13.34ab & $0.02 \mathrm{a}$ & $0.70 \mathrm{a}$ & $7.17 a$ & - & 90 A & - & $0.23 \mathrm{aA}$ \\
\hline$\S 100$ & 272.17a & $3.25 a$ & 1813a & $23.87 a$ & $5.84 a$ & $11.42 \mathrm{a}$ & $0.11 \mathrm{a}$ & $0.97 \mathrm{a}$ & $7.02 \mathrm{a}$ & - & $\uparrow 0 \mathrm{P}$ & - & $1.36 \mathrm{aB}$ \\
\hline$\S 200$ & 262.53a & $2.32 \mathrm{a}$ & $27.50 \mathrm{a}$ & $40.82 \mathrm{a}$ & $10.98 a$ & $23.39 \mathrm{~b}$ & $0.19 a$ & $0.93 a$ & 7.11a & - & ๑100 A & - & $0.67 \mathrm{aA}$ \\
\hline$\S 300$ & 234.73a & $6.42 \mathrm{a}$ & $25.01 \mathrm{a}$ & 38.38a & $6.68 a$ & 18.51ab & $0.18 \mathrm{a}$ & $0.91 \mathrm{a}$ & $7.00 \mathrm{a}$ & - & ๑100 P & - & $1.22 \mathrm{aA}$ \\
\hline$\S \mathrm{A}$ & $217.58 \mathrm{~A}$ & $3.44 \mathrm{~A}$ & $25.06 \mathrm{~A}$ & $31.27 \mathrm{~A}$ & $8.42 \mathrm{~A}$ & $17.30 \mathrm{~A}$ & $0.11 \mathrm{~A}$ & $0.50 \mathrm{~A}$ & $7.11 \mathrm{~A}$ & - & q200 A & - & $1.65 \mathrm{aB}$ \\
\hline$\S P$ & $277.44 \mathrm{~A}$ & $3.73 \mathrm{~A}$ & $17.41 \mathrm{~A}$ & $29.80 \mathrm{~A}$ & 6.63A & $16.03 \mathrm{~A}$ & $0.14 \mathrm{~A}$ & $1.26 \mathrm{~B}$ & $7.04 \mathrm{~A}$ & - & q200 P & - & $0.26 \mathrm{aA}$ \\
\hline & - & - & - & - & - & - & - & - & - & - & $\uparrow 300 \mathrm{~A}$ & - & $0.76 \mathrm{aA}$ \\
\hline- & - & - & - & - & - & - & - & - & - & - & $\uparrow 300 \mathrm{P}$ & - & $1.07 \mathrm{aA}$ \\
\hline$\overline{\mathrm{MF}}$ & 0.26 & 0.80 & 0.30 & 0.80 & 0.44 & 0.64 & 0.75 & $0.02 *$ & 0.49 & - & MF & - & 0.55 \\
\hline SWW & 0.88 & 0.06 & 0.55 & 0.08 & 0.39 & $0.03 *$ & 0.51 & 0.92 & 0.65 & - & SWW & - & 0.97 \\
\hline $\mathrm{SWW} * \mathrm{MF}$ & 0.82 & 0.34 & 0.56 & 0.93 & 0.14 & 0.50 & 0.40 & 0.93 & 0.93 & - & SWW*MF & - & $0.02 *$ \\
\hline $\mathrm{VC}(\%)$ & 50.71 & 74.24 & 82.31 & 52.68 & 72.82 & 39.54 & 172,82 & 83.17 & 3.75 & - & VC (\%) & - & 67.56 \\
\hline \multicolumn{14}{|c|}{ Cycle end } \\
\hline$\S 0$ & 107.83a & $1.33 \mathrm{a} 00$ & $1.72 \mathrm{a}$ & 14.19a & $16.92 \mathrm{a}$ & $13.37 \mathrm{a}$ & ns & $0.65 a$ & - & $1.80 \mathrm{a}$ & 90 A & 7,70aA & - \\
\hline$\S 100$ & $87.00 \mathrm{a}$ & $2.33 \mathrm{a} \infty 0$ & 2.06a & $12.27 \mathrm{a}$ & $16.40 \mathrm{a}$ & 17.79a & ns & $0.57 \mathrm{a}$ & - & $1.78 \mathrm{a}$ & 丹0 P & 7,41bA & - \\
\hline$\S 200$ & 114.17a & $2.83 \mathrm{a} \infty$ & $1.98 \mathrm{a}$ & $14.48 \mathrm{a}$ & $15.71 \mathrm{a}$ & $16.45 a$ & ns & $0.62 \mathrm{a}$ & - & $1.47 \mathrm{a}$ & \$100 A & 7,51aB & - \\
\hline$\S 300$ & 111.17a & $6.83 \mathrm{a} \infty$ & $2.11 \mathrm{a}$ & $19.03 a$ & $19.05 a$ & 16.19a & ns & $0.63 a$ & - & $1.49 \mathrm{a}$ & \$100 P & $6,67 \mathrm{aA}$ & - \\
\hline$\overline{\S A}$ & $80.25 \mathrm{~A}$ & $1.66 \mathrm{~A} \infty$ & $1.82 \mathrm{~A}$ & $12.64 \mathrm{~A}$ & $16.78 \mathrm{~A}$ & $14.98 \mathrm{~A}$ & ns & $0.64 \mathrm{~A}$ & - & $1.58 \mathrm{~A}$ & \200 A & 7.47aA & - \\
\hline$\S P$ & 129.83B & $5.00 \mathrm{~A} \infty$ & $2.12 \mathrm{~A}$ & 17.35A & $17.26 \mathrm{~A}$ & 16.92A & ns & 0.59A & - & $1.68 \mathrm{~A}$ & 丹200 P & $7.20 \mathrm{bA}$ & - \\
\hline - & - & - & - & - & - & - & - & - & - & - & |300 A & 7.29aA & - \\
\hline- & - & - & - & - & - & - & - & - & - & - & $\uparrow 300 \mathrm{P}$ & 7.19bA & - \\
\hline$\overline{\mathrm{MF}}$ & $0.05^{*}$ & 0.09 & 0.18 & 0.11 & 0.79 & 0.32 & ns & 0.35 & - & 0.68 & MF & $0.00 *$ & - \\
\hline SWW & 0.83 & 0.11 & 0.57 & 0.38 & 0.59 & 0.44 & ns & 0.74 & - & 0.66 & SWW & $0.01 *$ & - \\
\hline $\mathrm{SWW} * \mathrm{MF}$ & 0.70 & 0.37 & 0.53 & 0.21 & 0.83 & 0.86 & ns & 0.13 & - & 0.85 & SWW ${ }^{*} \mathrm{MF}$ & $0.02 *$ & - \\
\hline VC (\%) & 52.91 & 71.68 & 26.34 & 44.40 & 25.40 & 29.13 & ns & 20.40 & - & 36.24 & VC (\%) & 2.58 & - \\
\hline
\end{tabular}

$\S$ Means followed by the same low case letter in the column do not differ by Tukey test at 5\% significance for SWW and means followed by the same capital letter in the column do not differ by Tukey test at $5 \%$ significance for MF. ๆ Means followed by the same low case letter in the column do not differ by Tukey test at 5\% significance for the SWW statistical breakdown by MF and means followed by the same capital letter in the column do not differ by Tukey test at 5\% significance level for MF within SWW. A: MF absence; P: MF presence; *: Significant at 5\%; VC: variation coefficient; ns: non-significant values; $\infty$ variables with YeoJohnson transformation. Nutrients expressed in $\mathrm{mg} \mathrm{L}^{-1}$; EC expressed in $\mu \mathrm{S} \mathrm{m}^{-1}$.

In spite of not significant, the $\mathrm{NO}_{3}{ }^{-}+\mathrm{NO}_{2}{ }^{-}$concentrations tended to rise with increasing SWW doses and also with fertilizer addition (MF), both at the beginning and end of the culture cycle. Similar results were reported by AITA \& GIACOMINI (2008), MENEGHETTI (2010) SMANHOTTO et al. (2010), who found that the $\mathrm{NO}_{3}{ }^{-}$concentration increased with SWW application. This result is worrisome from the environmental point of view, considering the high possibility of surface and groundwater contamination. However, CAVANAGH et al. (2011) argue that lower residue doses may fertilize the crop, minimizing nitrate contamination risk in groundwater.

The $\mathrm{Ca}^{2+}$ and $\mathrm{Mg}^{2+}$ ions showed a growth trend with SWW and MF addition, however not significant. MAGGI et al. (2011) and MENEGHETTI (2010) evaluated the SWW and MF effect at different levels in soybean and baby corn, respectively, also observed an increase in the amounts of $\mathrm{Ca}^{2+}$, as there was an increase in SWW doses MF addition. According to MAGGI et al. (2011), the calcium in soil is strongly adsorbed than ammonium, potassium and magnesium, which perform a less intense leaching and, in fact, not enough to cause concern, in loss terms, when compared to other elements. Looking at Table 5, we observe that during the experimental period $\mathrm{Ca}^{2+}$ concentrations in leachate decreased. Similar results were obtained by FREITAS et al. (2004), who 
found that calcium concentrations in leachate from lysimeters with SWW application generally were lower at the corn crop cycle end than at the beginning. GOSS et al. (2010), regarding lysimeter drainage, observed $\mathrm{Ca}^{2+}, \mathrm{NO}_{3}{ }^{-}, \mathrm{Mg}^{2+}$ and $\mathrm{Na}^{+}$percolation along soil profile, which reached the leachate.

According to CONAMA Resolution 396/2008 (BRAZIL, 2008), it is considered as upper limits for the groundwater: 50; 100; 25; 300; 20; 1000 and $100 \mathrm{mg} \mathrm{L}^{-1}$ levels for $\mathrm{Cu}^{+2}, \mathrm{Fe}^{+2}, \mathrm{Mn}$, $\mathrm{NO}_{2}{ }^{-}, \mathrm{NO}_{3}{ }^{-}, \mathrm{Na}^{+}$and $\mathrm{Zn}^{+2}$, respectively. In this sense, all the elements assessed in this study, presented values above permitted so characterized as polluters for this water class.

\section{CONCLUSIONS}

We conclude that the swine wastewater can be partially used as fertilizer, once phosphorus and manganese are supplemented with mineral fertilizer. However, when defining the agronomically suitable dose for crop fertilization, one must consider environmental aspects: iron, copper, and zinc amounts in soil.

It was found that for higher SWW doses, significant concentrations of copper, iron, manganese, nitrate + nitrite, sodium and zinc in the leachate material, which reinforces the need to obtain an agronomic and environmentally appropriate dose.

\section{ACKNOWLEDGMENTS}

CNPq for research funding, FPTI for the granting of master's scholarship, and to PGEAGRI and SIMEPAR.

\section{REFERENCES}

AITA, C.; GIACOMINI, S.J. Nitrato no solo com a aplicação de dejetos líquidos de suínos no milho em plantio direto. Revista Brasileira de Ciência do Solo, Viçosa - MG, v.32, p.2101-2111, 2008.

APHA - AMERICAN PUBLIC HEALTH ASSOCIATION - APHA; AWWA; WEF. Standard methods for the examination of water and wastewater. $19^{\text {th }}$ ed. New York: American Public Health Association, 1995. p.1193.

ANAMI, M.H.; SAMPAIO, S.C.; SUSZEK, M.; DAMASCENO, S.; QUEIROZ, M.M.F. Deslocamento miscível de nitrato e fosfato proveniente de água residuária da suinocultura em colunas de solo. Revista Brasileira de Engenharia Agrícola e Ambiental, Campina Grande, v.12, n.1, p.75-80, 2008.

ASSMANN, T.S.; BRAIDA, J.A.; CASSOL, L.C.; MAGIERO, C.; MANTELI, C.; GRIZ, E. Produção de matéria seca de forragem e acúmulo de nutrientes em pastagem anual de inverno tratada com esterco de suínos. Revista Ciência Rural, Santa Maria, v.39, n.8, p.2408-2418, 2009.

BERTOL, O. J.; RIZZI, N. E.; FAVARETTO, N.; LANA, M. C. Phosphorus loss by surface runoff in no-till system under mineral and organic fertilization. Scientia Agrícola, Piracicaba, v.67, p.7177, 2010.

BERWANGER, A. L.; CERETTA, C. A.; SANTOS, D. R. Alterações no teor de fósforo no solo com aplicação de dejetos líquidos de suínos. Ciência do Solo, Viçosa - MG, v.32, p.2525-2532, 2008.

BRASIL - Conselho Nacional de Meio Ambiente: Resolução CONAMA nº 396. Diário Oficial da União, Brasília, 3 mar. 2008.

CAOVILLA, F.A.; SAMPAIO, S.C.; SMANHOTTO, A.; NOBREGA, L.H. QUEIROZ, M.H.F. GOMES, B.M. Características químicas de solo cultivado com soja e irrigado com água residuária 
da suinocultura. Revista Brasileira de Engenharia Agrícola e Ambiental, Campina Grande, v.14, n.7, p.692-697, 2010.

CAVANAGH, A.; GASSER, M.O.; LABRECQUE, M. Pig slurry as fertilizer on willow plantation. Biomass and Bioenergy, Oxforf, v.30, p.1-9, 2011.

CERETTA, C.A.; BASSO, C.J.; PAVINATO, P.S.; TRENTIN, E.E.; GIROTTO, E. Produtividade de grãos de milho, produção de matéria seca e acúmulo de nitrogênio, fósforo e potássio na rotação aveia preta/milho/nabo forrageiro com aplicação de dejeto líquido de suínos. Revista Ciência Rural, Santa Maria, v.35, n.6, p.1287-1295, 2005.

CESARINO, R. de O. Milho fertirrigado com dejetos de suínos para ensilagem. 2006. 52 f.

Dissertação (Mestrado em Ciência Animal) - Universidade José do Rosário Vellano, Alfenas, 2006.

CRUZ, J.C.; GARCIA, J.C.; FILHO, I.A.P. Caracterização dos sistemas de produção de milho para altas produtividades. (Circular Técnica, 124). Sete Lagoas: Embrapa Milho e Sorgo, 2009. $14 \mathrm{p}$.

DAL BOSCO, T.C.; IOST, C.; SILVA, L.N.; CARNELLOSI, C.F.; EBERT, D.C.; SCHREINER, J.S.; SAMPAIO, S.C. utilização de água residuária de suinocultura em propriedade agrícola estudo de caso. Revista Irriga, Botucatu, v.13, n. 1, p.139-144, 2008.

DOBLINSKI, A.F.; SAMPAIO, S.C.; SILVA, V.R. da; Nóbrega, L.H.P.; Gomes, S.D.; DAL BOSCO, T.C. Nonpoint source pollution by swine farming wastewater in bean crop. Revista Brasileira de Engenharia Agrícola e Ambiental, Campina Grande, v.14, p.87-93, 2010.

EMBRAPA - Empresa Brasileira de Pesquisa Agropecuaria. Manual de métodos de análises de solo. 2.ed. Rio de Janeiro, Embrapa. 1997. 212 p.

EMBRAPA - Empresa Brasileira de Pesquisa Agropecuaria. Centro Nacional de Pesquisa de Solos. Sistema brasileiro de classificação de solos. 2.ed. Rio de Janeiro: Embrapa, 2006. 374 p.

FEIGIN, A.; RAVINA, I.; SHALHEVET, J. Irrigation with treated sewage effluent: Management for environmental protection. Berlim: Springer-Verlag, 1991. 224 p.

FREITAS, W. S.; OLIVEIRA, R.A.; PINTO, F.A.; CECON, P.R.; GALVÃO, J.C.C. Efeito da aplicação de águas residuárias de suinocultura sobre produção do milho para silagem. Revista Brasileira de Engenharia Agrícola e Ambiental, Campina Grande, v.8, n.1, p.120-125, 2004.

GIROTTO, E; CERETTA, C.A.; BRUNETTO, G.; SANTOS, D.R.; SILVA, L. S.; LOURENZI, C.R. ; LORENSINI, F.; VIEIRA, R.C.B.; SCHMATZ, R. Acúmulo e formas de cobre e zinco no solo após aplicações sucessivas de dejeto líquido de suínos. Revista Brasileira de Ciência do Solo, Viçosa - MG, v.34, p.955-965, 2010.

GONÇALVES, R.A.B.; FOLEGATTI, M.V.; GLOAGUEN, T.V.; LIBARDI, P.L. MONTES, C.R.; LUCAS, Y.; DIAS, C.T.S.; MELFI, A.J. Hidraulic conductivity of a soil irrigated whit treated sewage effluent. Geoderma, Amsterdam, v.139, p.241-248, 2007.

GOSS, M.J.; EHLERS, W.; UNC, A. The role of lysimeters in the development of our understanding of processes in the vadose zone relevant to contamination of groundwater aquifers. Physics and Chemistry of the Earth, v.35, p.913-926, 2010.

IAPAR - Instituto Agronômico do Paraná. Cartas climáticas do Estado do Paraná. Londrina: IAPAR, 1998.

KESSLER, N.C.H.; SAMPAIO, S.C.; LUCAS, S.D.M.; SORACE, M.; CITOLIN, A.C. Swine wastewater associated with mineral fertilization in soybean (Glycine max L.) cultures: $9^{\text {th }}$ production cycle. Journal of Food, Agriculture \& Environment, Helsinki, v.11, n.2, p.936-942, 2013. 
KING, L. D.; WESTERMAN, P.W.; CUMMINGS, G.A.; OVERCASH, M.R.; BURNS, J.C. Swine lagoon effluent applied to 'Coastal' Bermudagrass: II Effects on soil. Journal of Environmental Quality, Madison, v.14, p.14-21, 1985.

LUCAS, S. D. M.; SAMPAIO, S. C.; URIBE-OPAZO, M.A.; GOMES, S. D.; KESSLER, N. C. H.; PRADO, N. V. Long-term behavior of $\mathrm{Cu}$ and $\mathrm{Zn}$ in soil and leachate of an intensive no-tillage system under swine wastewater and mineral fertilization. African Journal of Agricultural Research, Sapele, v. 8, n.7, p.639-647, 2013.

MAGGI, C.F.; FREITAS, C.L.F.; SAMPAIO, S.C.; DIETER, J. Lixiviação de nutrientes em solo cultivado com aplicação de água residuária de suinocultura. Revista Brasileira de Engenharia Agrícola e Ambiental, Campina Grande, v.15, p.170-177, 2011.

MALAVOLTA, E. Manual de nutrição mineral de plantas. São Paulo: Agronômica Ceres, 2006. $638 \mathrm{p}$.

MEDEIROS, C.; ALBUQUERQUE, J. A.; MAFRA, A. L. DALLA ROSA, J.; GATIBONI, L. C. Relação cálcio: magnésio do corretivo da acidez do solo na nutrição e no desenvolvimento inicial de plantas de milho em Cambissolo Húmico Álico. Semina: Ciências Agrárias, Londrina, v.29, n.4, p.799-806, 2008.

MENEGHETTI, A.M. Aspectos ambientais e agronômicos da cultura do minimilho sob aplicação de água residuária da agricultura tratada após lagoa de estabilização. 2010. 242 f. Tese (Doutorado em Engenharia Agrícola) - Universidade Estadual do Oeste do Paraná , Cascavel, 2010.

OLIVEIRA, R.A.; FREITAS, W.S.; GALVÃO, J.C.C.; PINTO, F.A.; CECON, P.R. Efeito da aplicação de águas residuárias de suinocultura nas características nutricionais do milho. Revista Brasileira de Milho e Sorgo, Sete Lagoas, v.3, n.3, p.357-369, 2004.

PRIOR, M. Efeito da água residuária de suinocultura no solo e na cultura do milho. 2008. 120 f. Tese (Doutorado em Agronomia) - Universidade Estadual Paulista, Botucatu, 2008.

PRIOR, M.; SMANHOTTO, A.; SAMPAIO, S. C.; NÓBREGA, L.H.P.; OPAZO, M.A.U.; DIETER, J. (2009), Acúmulo e percolação de fósforo no solo devido a aplicação de água residuária da suinocultura na cultura do milho (Zea mays L.). Revista Pesquisa Aplicada \& Agrotecnologia, Guarapuava, v.2, p.89-96, 2009.

QUEIROZ, F.M.; MATOS, A.T.; PEREIRA, O.G.; OLIVEIRA, R.A. Características químicas de solo submetido ao tratamento com esterco líquido de suínos e cultivado com gramíneas forrageiras. Revista Ciência Rural, Santa Maria, v.34, n.5, p.1487-1492, 2004.

RAIJ, B.V. Fertilidade do solo e adubação. São Paulo: Agronômica Ceres, 1991. 343 p.

RAIJ, B.V.; ANDRADE, J.C. de; CANTARELLA, H.; QUAGGIO, J.A. Análise química para avaliação da fertilidade de solos tropicais. Campinas: Instituto Agronômico, 2001. 285 p.

SAMPAIO, S.C.; FIORI, M.G.S.; OPAZO, M.A.U.; NÓBREGA, L.H.P. Comportamento das formas de nitrogênio em solo cultivado com milho irrigado com água residuária da suinocultura. Revista Brasileira de Engenharia Agrícola, Jaboticabal, v.30, p.138-149, 2010a.

SAMPAIO, S.C.; CAOVILLA, F.A.; OPAZO, M.A.U.; NÓBREGA, L.H.P.; SUSZEK, M.; SMANHOTTO, A. Lixiviação de íons em colunas de solo deformado e indeformado. Revista Brasileira de Engenharia Agrícola, Jaboticabal, v.30, p.150-159, $2010 \mathrm{~b}$.

SCHERER, E.E.; BALDISSERA, I.T.; NESI, C.N. Propriedades químicas de um latossolo vermelho sob plantio direto e adubação com esterco de suínos. Revista Brasileira de Ciência do Solo, Viçosa - MG, v.31, p.23-131, 2007.

SEIDEL, E.P.; GONÇALVES JUNIOR, A.C.; VANIN, J.P.; STREY, L.; SCHWANTES, D.; NACKE, H. Aplicação de dejetos de suínos na cultura do milho cultivado em sistema de plantio direto. Revista Acta Scientiarium Technology. Maringá, v.32, n.2, p.113-117, 2010. 
SILVA, R.G.; GALVÃO, J. C. C.; MIRANDA, G. V.; SILVA, D. G.; ARNHOLD, E. Produtividade de milho em diferentes sistemas produtivos. Revista verde de agroecologia e desenvolvimento sustentável, Mossoró, v.2, n.2, p.136-141, 2007.

SMANHOTTO, A. Aplicação de água residuária de suinocultura em solo cultivado com soja. 2008. 108 f. Tese (Doutorado em Agronomia) - Universidade Estadual Paulista Júlio de Mesquita Filho, Faculdade De Ciências Agronômicas, Botucatu, 2008.

SMANHOTTO, A.; SOUZA, A.P.; SAMPAIO, S.C.; NÓBREGA, L.H.P.; PRIOR, M. Cobre e zinco no material percolado e no solo com a aplicação de água residuaria de suinocultura em solo cultivado com soja. Revista Brasileira de Engenharia Agrícola, Jaboticabal, v.30, n.2, p.347-357, 2010.

TEDESCO, M.J.; GIANELLO, C.; BISSANI, C.A.; BOHNEN, H.; VOLKWEISS, S. J. Análise de solo, plantas e outros materiais. Porto Alegre: UFRGS, 1995. 174 p.

VELOSO, A.V. Avaliação ambiental da produção de suínos em sistema de camas sobrepostas e reaproveitamento dos resíduos como biofertilizante na cultura do milho. 2010. 61 f. Dissertação (Mestrado em Produção Vegetal) - Universidade Federal dos Vales do Jequitinhonha e Mucuri, Diamantina, 2010. 